\title{
Flavobacterium ginsenosidimutans sp. nov., a bacterium with ginsenoside converting activity isolated from soil of a ginseng field
}

Correspondence

Wan-Taek Im wandra@kaist.ac.kr

Tae-Hoo Yi

drhoo@khu.ac.kr

\author{
Jung-Eun Yang, Se-Young Kim, Wan-Taek $\operatorname{Im}^{\dagger}$ and Tae-Hoo Yi
}

Department of Oriental Medicinal Material and Processing, College of Life Science, Kyung Hee University, 1 Seocheon, Kihung Yongin, Kyunggi 449-701, Republic of Korea
The genus Flavobacterium, created by Bergey et al. (1923), has a rapidly growing membership, as demonstrated by the multitude of novel species that have been proposed in recent years, e.g. Flavobacterium caeni (Liu et al., 2010), Flavobacterium reichenbachii (Ali et al., 2009), Flavobacterium chungangense (Kim et al., 2009), Flavobacterium cheniae (Qu et al., 2008) and Flavobacterium aquidurense (Cousin et al., 2007). The genus belongs to the family Flavobacteriaceae, phylum 'Bacteroidetes', and, at the time of writing, comprised 89 species, with Flavobacterium aquatile as the type species (Euzéby, 1997). Species of the genus Flavobacterium have been isolated from diverse habitats such as fresh and salt water, soil, sediment, sea ice, diseased fish and microbial mats (Bernardet \& Bowman, 2006). Furthermore, the description of the genus has been emended several times (Bernardet $e t$ al.,

The GenBank/EMBL/DDBJ accession number for the 16S rRNA gene sequence of strain $\mathrm{THG} 01^{\top}$ is GU138377.

A supplementary table is available with the online version of this paper.

tPresent address: KI for the BioCentury, Korea Advanced Institute of Science and Technology, 373-1, Guseong-dong, Yuseong-gu, Daejeon 305-701, Republic of Korea.
1996). Flavobacterium species are generally Gram-negative, aerobic, non-spore-forming, yellow-pigmented, rod-shaped bacteria that are usually motile by gliding and have menaquinone-6 (MK-6) as the major respiratory quinone. Most members of the genus Flavobacterium have DNA G + C contents in the range $30-37 \mathrm{~mol} \%$. In this paper, a polyphasic taxonomic approach was used to characterize a novel Flavobacterium-like strain, THG $01^{\mathrm{T}}$, isolated from the soil of a ginseng field.

Strain THG $01^{\mathrm{T}}$ was isolated from soil samples from a ginseng field of Pocheon province, South Korea. Soil samples were thoroughly suspended in $50 \mathrm{mM}$ phosphate buffer ( $\mathrm{pH} 7.0$ ) and spread on modified R2A agar (Liu et al., 2006). The plates were incubated at $28{ }^{\circ} \mathrm{C}$ for 2 weeks. Single colonies on the plates were purified by transferring them onto new plates of R2A agar (BD) followed by further incubation. One isolate, THG $01^{\mathrm{T}}$, was cultured routinely on R2A agar or nutrient agar (BD) at $28{ }^{\circ} \mathrm{C}$ and preserved in a glycerol solution $\left(20 \%\right.$, w/v) at $-70{ }^{\circ} \mathrm{C}$.

Gram-reaction testing was performed by the non-staining method as described by Buck (1982). Cell morphology was 
observed at $\times 1000$ magnification with a light microscope (BX50; Olympus) using cells grown for $48 \mathrm{~h}$ at $28{ }^{\circ} \mathrm{C}$ on nutrient agar. Catalase activity was determined by bubble production in $3 \%(\mathrm{v} / \mathrm{v}) \mathrm{H}_{2} \mathrm{O}_{2}$ and oxidase activity was determined using $1 \%(\mathrm{w} / \mathrm{v})$ tetramethyl $p$-phenylenediamine. Carbon-source utilization and some enzyme activities were tested by using API 20NE, ID 32GN and API ZYM kits according to the instructions of the manufacturer (bioMérieux). Tests for hydrolysis of DNA (DNASE agar, Scharlau; DNase activity revealed by flooding the plates with $1 \mathrm{M} \mathrm{HCl}$ ), casein and starch (Atlas, 1993) were evaluated after 5 days of incubation at $28{ }^{\circ} \mathrm{C}$. Conversion of ginsenoside $\mathrm{Rb}_{1}$ was performed using TLC analysis as described by Kim et al. (2005). Growth at different temperatures $\left(4,10,18,25,28,35,37\right.$ and $\left.42{ }^{\circ} \mathrm{C}\right)$ and $\mathrm{pH}(\mathrm{pH} 5.0-10.0$ at intervals of 0.5$)$ was assessed after 5 days of incubation. For the $\mathrm{pH}$ experiments, three different buffers were used (final concentration, $50 \mathrm{mM}$ ): acetate buffer was used for $\mathrm{pH}$ 5.0-5.5; phosphate buffer was used for $\mathrm{pH}$ 6.0-8.0; and Tris buffer was used for $\mathrm{pH}$ 8.5-10.0. Salt tolerance was tested in nutrient broth (BD) supplemented with $1-10 \%(\mathrm{w} / \mathrm{v}) \mathrm{NaCl}$ after 5 days of incubation. Growth was estimated by monitoring the $\mathrm{OD}_{600}$. Growth on nutrient agar, tryptic soy agar (TSA) and MacConkey agar was also evaluated at $28{ }^{\circ} \mathrm{C}$.

An almost-complete 16S rRNA gene sequence for strain THG $01^{\mathrm{T}}$ was determined as described below. Extraction of the genomic DNA was achieved using a commercial genomic DNA-extraction kit (Solgent). The 16S rRNA gene was amplified from the chromosomal DNA using the universal bacterial primer set, comprising $9 \mathrm{~F}$ and 1512R, and the purified PCR products were sequenced by Solgent, Daejeon, South Korea (Im et al., 2010). The full sequence of the 16S rRNA gene was compiled using SeqMan software (DNASTAR). The 16S rRNA gene sequences of related taxa were obtained from GenBank. Multiple alignments were performed by using the CLUSTAL_X program (Thompson et al., 1997). Gaps were edited in the BioEdit program (Hall, 1999). Evolutionary distances were calculated using the Kimura two-parameter model (Kimura, 1983). The phylogenetic tree was constructed using the neighbour-joining (Saitou \& Nei, 1987) and maximum-parsimony (Fitch, 1971) methods in the MEGA4 program (Kumar et al., 2008), with bootstrap values based on 1000 replications (Felsenstein, 1985).

For measurement of the $\mathrm{G}+\mathrm{C}$ content of the chromosomal DNA, genomic DNA of the novel strain was extracted and purified as described by Moore \& Dowhan (1995) and $\mathrm{G}+\mathrm{C}$ content was determined as described by Mesbah et al. (1989) using reverse-phase HPLC. Cellular fatty acid profiles were determined for strains grown on nutrient agar (BD) at $28{ }^{\circ} \mathrm{C}$ for 2 days. The cellular fatty acids were saponified, methylated and extracted according to the protocol of the Sherlock Microbial Identification System (MIDI). Fatty acids analysed by GC (6890; Hewlett Packard) were identified by the Microbial Identification software package (Sasser, 1990). For isoprenoid quinone analysis, strain THG $01^{\mathrm{T}}$ was grown on modified nutrient broth for 2 days at $28{ }^{\circ} \mathrm{C}$. Collected cells were lyophilized for $24 \mathrm{~h}$. Isoprenoid quinones were extracted with chloroform/methanol $(2: 1, \mathrm{v} / \mathrm{v})$, evaporated under vacuum conditions and re-extracted in $\mathrm{n}$-hexane/water $(1: 1, \mathrm{v} / \mathrm{v})$. The crude $\mathrm{n}$-hexane/quinone solution was purified using Sep-Pak Vac silica cartridges (Waters) and subsequently analysed by HPLC as described previously (Hiraishi et al., 1996). DNA-DNA hybridization experiments were performed between strain THG $01^{\mathrm{T}}$ and closely related type strains of species of the genus Flavobacterium according to Ezaki et al. (1989) using photobiotin-labelled DNA probes and micro-dilution wells. Hybridization was performed with five replications for each sample. The highest and lowest values obtained for each sample were excluded and the means of the remaining three values were converted to DNA-DNA relatedness values (\%).

Table 1. Physiological characteristics of strain $T H G 01^{\top}$ and related type strains of species of genus Flavobacterium

Strains: 1 , THG $01^{\mathrm{T}} ; 2$, F. anhuiense $\mathrm{D}^{\mathrm{T}} ; 3$, F. defluvii $\mathrm{EMB} 117^{\mathrm{T}}$; 4, F. denitrificans $\mathrm{ED}^{\mathrm{T}}$; 5, F. daejeonense $\mathrm{GH} 1-10^{\mathrm{T}} ; 6$, F. johnsoniae $\mathrm{UW} 01^{\mathrm{T}}$ (all data are from this study). All strains were Gramnegative, rod-shaped, catalase- and oxidase-positive, and tolerated $1 \% \mathrm{NaCl}$. In API 20NE and ID 32GN tests, all strains were positive for hydrolysis of casein and starch, and assimilation of D-glucose, L-arabinose, D-mannose, maltose and glycogen, but negative for assimilation of the following substrates: 2-ketogluconate, 3-hydroxybenzoate, 3-hydroxybutyrate, 4-hydroxybenzoate, 5-ketogluconate, acetate, adipate, caprate, citrate, D-mannitol, D-ribose, D-sorbitol, myo-inositol, itaconate, lactate, L-histidine, L-proline, L-serine, malonate, phenylacetate, propionate, suberate and valerate. In API ZYM tests, all strains were positive for $\beta$-glucosidase and $\beta$-galactosidase, but negative for esterase (C4), esterase lipase (C8), lipase (C14), cystine arylamidase, trypsin, $\alpha$-chymotrypsin, $\alpha$-galactosidase, $\beta$-glucuronidase, $\alpha$-mannosidase and $\alpha$-fucosidase.

\begin{tabular}{|c|c|c|c|c|c|c|}
\hline Characteristic & 1 & 2 & 3 & 4 & 5 & 6 \\
\hline Indole production & - & - & - & - & + & - \\
\hline Hydrolysis of DNA & - & + & + & + & + & + \\
\hline \multicolumn{7}{|l|}{ API $20 \mathrm{NE} / \mathrm{ID} 32 \mathrm{GN}$ tests } \\
\hline Nitrate reduction to nitrite & - & - & - & + & - & + \\
\hline \multicolumn{7}{|l|}{ Assimilation of carbon sources: } \\
\hline L-Fucose & + & - & - & - & - & - \\
\hline Malate & - & + & - & - & + & - \\
\hline Melibiose & + & + & - & + & - & - \\
\hline Salicin & + & - & + & - & - & - \\
\hline Sucrose & + & - & - & + & - & + \\
\hline \multicolumn{7}{|l|}{ API ZYM results } \\
\hline$N$-Acetyl- $\beta$-glucosaminidase & - & - & - & - & - & + \\
\hline Acid phosphatase & + & - & + & + & - & + \\
\hline Alkaline phosphatase & + & + & + & + & + & - \\
\hline Leucine arylamidase & + & - & - & - & + & + \\
\hline $\begin{array}{l}\text { Naphthol-AS-BI- } \\
\text { phosphohydrolase }\end{array}$ & - & - & + & - & + & + \\
\hline Valine arylamidase & + & - & + & + & - & - \\
\hline
\end{tabular}




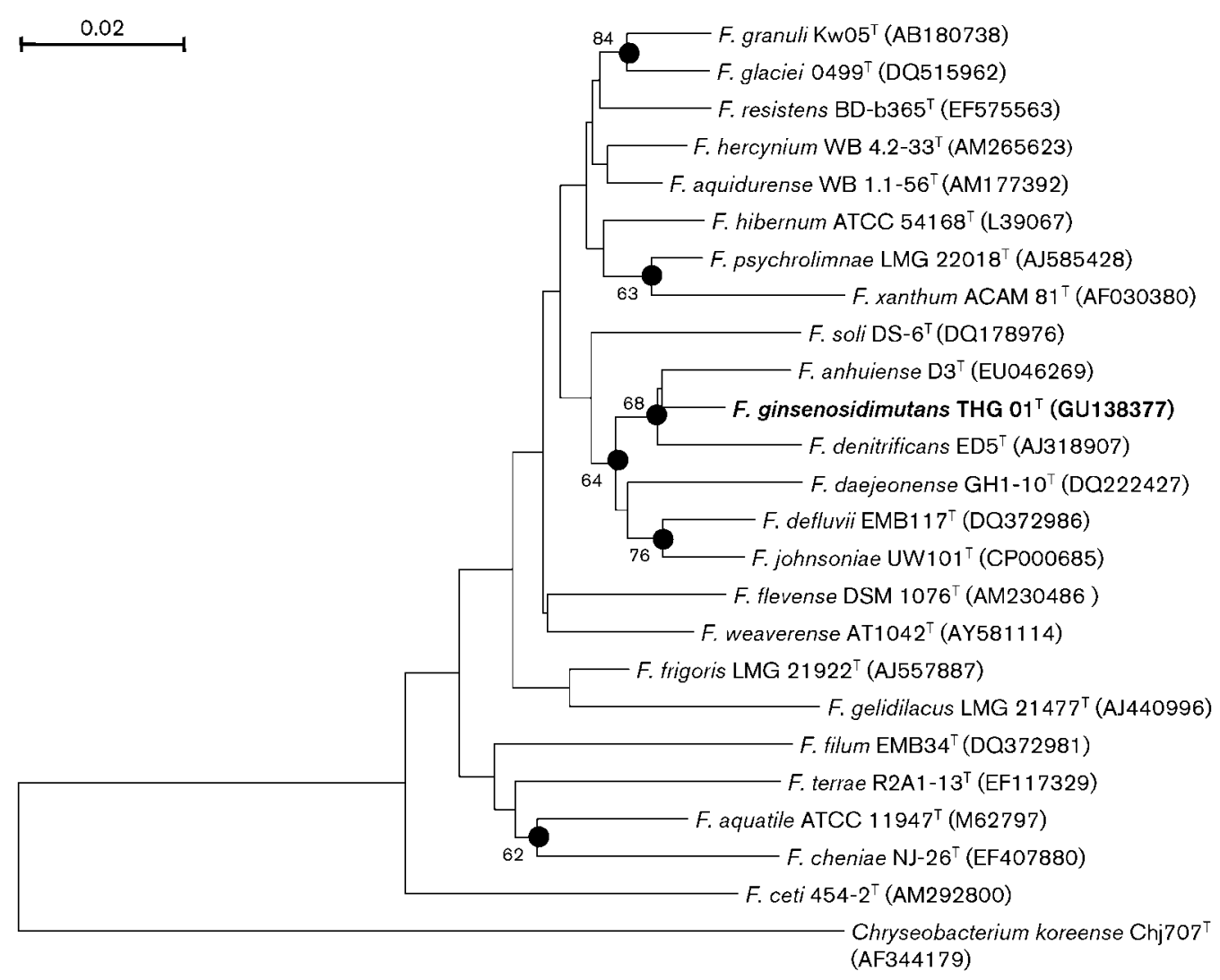

Fig. 1. Neighbour-joining phylogenetic tree constructed from a comparative analysis of 16S rRNA gene sequences showing the relationship between strain THG $01^{\top}$ and related strains. Filled circles at nodes indicate generic branches that were also recovered by using maximum-parsimony algorithms. Bootstrap values (expressed as percentages of 1000 replications) >65 \% are shown at the branch points. Bar, 0.02 substitutions per nucleotide position.

Cells of strain THG $01^{\mathrm{T}}$ were Gram-negative, aerobic, nonspore-forming, non-motile, rod-shaped, and oxidase- and catalase-positive. Colonies grown on nutrient agar plates for 2 days were smooth, transparent and deep orange in colour. On nutrient agar, THG $01^{\mathrm{T}}$ was able to grow at $10-37^{\circ} \mathrm{C}$, but not at 4 or $42{ }^{\circ} \mathrm{C}$. The isolate grew on TSA (BD), but not on MacConkey agar. The isolate could hydrolyse starch, casein and DNA. It had $\beta$-glucosidase activity linked with ginsenoside-converting activity. It could convert ginsenoside $\mathrm{Rb}_{1}\{3-O-[\beta$-D-glucopyranosyl-(1-2)- $\beta$-D-glucopyranosyl]20 -O-[ $\beta$-D-glucopyranosyl-(1-6)- $\beta$-D-glucopyranosyl]-20(S) -protopanaxadiol $\}$ to $\mathrm{C}-\mathrm{K}$ [20-O-( $\beta$-D-glucopyranosyl)20(S)-protopanaxadiol]. Physiological characteristics of strain THG $01^{\mathrm{T}}$ are summarized in the species description and a comparison of selective characteristics of strain THG $01^{\mathrm{T}}$ and related type strains is given in Table 1.

The 16S rRNA gene sequence of strain THG $01^{\mathrm{T}}$ determined in this study was a continuous stretch of 1386 bp (positions 50-1458 with respect to the Escherichia coli numbering system). Sequence similarity calculations using the EzTaxon server [http://www.eztaxon.org/; Chun et al. (2007)] indicated that the closest relatives of strain THG $01^{\mathrm{T}}$ were Flavobacterium anhuiense $\mathrm{D}^{\mathrm{T}}(97.5 \%$ sequence similarity), Flavobacterium johnsoniae $\mathrm{UW} 101^{\mathrm{T}}$ $(96.8 \%)$ and Flavobacterium denitrificans $\mathrm{ED}^{\mathrm{T}}(96.7 \%)$. Lower sequence similarities $(<96.7 \%)$ were found with strains of all other recognized species of the family Flavobacteriaceae. This relationship between strain THG $01^{\mathrm{T}}$ and other members of the genus Flavobacterium was also evident in the phylogenetic tree, which used over 1350 nt (Fig. 1). The DNA-DNA relatedness value between strain THG $01^{\mathrm{T}}$ and Flavobacterium anhuiense $\mathrm{D}^{\mathrm{T}}$ was $11 \%$. This low value, together with $16 \mathrm{~S}$ rRNA gene sequence similarities of $<97 \%$ with other strains, suggested that strain THG $01^{\mathrm{T}}$ represented a novel Flavobacterium species according to Wayne et al. (1987) and Stackebrandt \& Goebel (1994).

The DNA $\mathrm{G}+\mathrm{C}$ content of strain THG $01^{\mathrm{T}}$ was $32.1 \mathrm{~mol} \%$. The respiratory quinone system of strain THG $01^{\mathrm{T}}$ was MK-6, which was consistent with the quinone systems of members of the genus Flavobacterium. The fatty acid profiles of isolate THG $01^{\mathrm{T}}$ and five recognized species of the genus Flavobacterium are shown in Supplementary Table S1 (available in IJSEM Online). The fatty acid profile of strain THG $01^{\mathrm{T}}$ was composed mainly of iso- $\mathrm{C}_{15: 0}(24.7 \%), \mathrm{C}_{16: 1} \omega 7 c$ and/or $\mathrm{C}_{16: 1} \omega 6 c$ 
$(14.6 \%)$, iso- $\mathrm{C}_{15: 0} 3-\mathrm{OH}(8.5 \%)$ and iso- $\mathrm{C}_{17: 0} 3-\mathrm{OH}$ $(8.2 \%)$, fatty acids that are typical of those of members of the genus Flavobacterium.

In summary, the characteristics of strain THG $01^{\mathrm{T}}$ were consistent with those of members of the genus Flavobacterium with regard to morphological, biochemical and chemotaxonomic properties. However, on the basis of phylogenetic distances between strain THG $01^{\mathrm{T}}$ and recognized species of the genus Flavobacterium, as indicated by $16 \mathrm{~S}$ rRNA gene sequence similarity values and the combination of unique phenotypic characteristics (Table 1) and low DNA-DNA relatedness values, strain THG $01^{\mathrm{T}}$ should be assigned to the genus Flavobacterium as a representative of a novel species, for which the name Flavobacterium ginsenosidimutans sp. nov. is proposed.

\section{Description of Flavobacterium ginsenosidimutans sp. nov.}

Flavobacterium ginsenosidimutans (gin.se.no.si.di.mu'tans. N.L. n. ginsenosidum ginsenoside; L. part. adj. mutans transforming, converting; N.L. part. adj. ginsenosidimutans ginsenoside-converting).

Cells are Gram-negative, aerobic, yellow-pigmented, nonmotile, non-spore-forming and rod-shaped, $0.2-0.4 \mu \mathrm{m}$ in diameter and 1.0-1.5 $\mu \mathrm{m}$ in length, after cultivation on R2A agar for 2 days. Colonies grown on nutrient agar or R2A agar plates for 2 days are smooth, transparent and deep orange in colour. Grows at $10-37{ }^{\circ} \mathrm{C}$ and $\mathrm{pH} 5.5-10.0$, but not at 4 or $42{ }^{\circ} \mathrm{C}$. Optimum growth occurs at $25-30{ }^{\circ} \mathrm{C}$ and $\mathrm{pH}$ 7.0. Growth occurs in the absence of $\mathrm{NaCl}$ and in the presence of $1.0 \%(\mathrm{w} / \mathrm{v}) \mathrm{NaCl}$, but not in $2.0 \%(\mathrm{w} / \mathrm{v}) \mathrm{NaCl}$. Catalase- and oxidase-positive. Data for carbon assimilation tests (API ID 32GN, API 20NE) and enzyme activities (API $\mathrm{ZYM}$ ) are listed in Table 1 . MK-6 is the predominant menaquinone; iso- $\mathrm{C}_{15: 0}$, iso- $\mathrm{C}_{15: 0} 3-\mathrm{OH}$ and $\mathrm{C}_{16: 1} \omega 7 c$ and/ or $\mathrm{C}_{16: 1} \omega 6 \mathrm{c}$ are the major cellular fatty acid components.

The type strain is THG $01^{\mathrm{T}} \quad\left(=\mathrm{KACC} \quad 14525^{\mathrm{T}}=\mathrm{JCM}\right.$ $\left.16720^{\mathrm{T}}\right)$, isolated from the soil of a ginseng field in Pocheon province, South Korea. The genomic DNA G + C content of the type strain is $32.1 \mathrm{~mol} \%$.

\section{Acknowledgements}

This work was supported by the 2010 research program of Rural Development Administration and a grant from the Kyung Hee University in 2010 (20100177), Republic of Korea.

\section{References}

Ali, Z., Cousin, S., Frühling, A., Brambilla, E., Schumann, P., Yang, Y. \& Stackebrandt, E. (2009). Flavobacterium rivuli sp. nov., Flavobacterium subsaxonicum sp. nov., Flavobacterium swingsii sp. nov. and Flavobacterium reichenbachii sp. nov., isolated from a hard water rivulet. Int J Syst Evol Microbiol 59, 2610-2617.

Atlas, R. M. (1993). Handbook of Microbiological Media. Edited by L. C. Parks. Boca Raton, FL: CRC Press.
Bergey, D. H., Harrison, F. C., Breed, R. S., Hammer, B. W. \& Huntoon, F. M. (editors) (1923). Genus II. Flavobacterium gen. nov. In Bergey's Manual of Determinative Bacteriology, pp. 97-117. Baltimore: Williams \& Wilkins.

Bernardet, J. F. \& Bowman, J. P. (2006). The genus Flavobacterium. In The Prokaryotes. A Handbook on the Biology of Bacteria, 3rd edn, vol. 7, pp. 481-531. Edited by M. Dworkin, S. Falkow, E. Rosenberg, K. H. Schleifer \& E. Stackebrandt. New York: Springer.

Bernardet, J.-F., Segers, P., Vancanneyt, M., Berthe, F., Kersters, K. \& Vandamme, P. (1996). Cutting a Gordian knot: emended classification and description of the genus Flavobacterium, emended description of the family Flavobacteriaceae, and proposal of Flavobacterium hydatis nom. nov. (basonym, Cytophaga aquatilis Strohl and Tait 1978). Int J Syst Bacteriol 46, 128-148.

Buck, J. D. (1982). Nonstaining (KOH) method for determination of gram reactions of marine bacteria. Appl Environ Microbiol 44, 992993.

Chun, J., Lee, J.-H., Jung, Y., Kim, M., Kim, S., Kim, B. K. \& Lim, Y. W. (2007). EzTaxon: a web-based tool for the identification of prokaryotes based on $16 \mathrm{~S}$ ribosomal RNA gene sequences. Int J Syst Evol Microbiol 57, 2259-2261.

Cousin, S., Päuker, O. \& Stackebrandt, E. (2007). Flavobacterium aquidurense sp. nov. and Flavobacterium hercynium sp. nov., from a hard-water creek. Int J Syst Evol Microbiol 57, 243-249.

Euzéby, J. P. (1997). List of bacterial names with standing in nomenclature: a folder available on the Internet. Int J Syst Bacteriol 47, 590-592. http://www.bacterio.cict.fr

Ezaki, T., Hashimoto, Y. \& Yabuuchi, E. (1989). Fluorometric deoxyribonucleic acid-deoxyribonucleic acid hybridization in microdilution wells as an alternative to membrane filter hybridization in which radioisotopes are used to determine genetic relatedness among bacterial strains. Int J Syst Bacteriol 39, 224-229.

Felsenstein, J. (1985). Confidence limits on phylogenies: an approach using the bootstrap. Evolution 39, 783-791.

Fitch, W. M. (1971). Toward defining the course of evolution: minimum change for a specific tree topology. Syst Zool 20, 406-416.

Hall, T. A. (1999). BioEdit: a user-friendly biological sequence alignment editor and analysis program for Windows 95/98/NT. Nucleic Acids Symp Ser 41, 95-98.

Hiraishi, A., Ueda, Y., Ishihara, J. \& Mori, T. (1996). Comparative lipoquinone analysis of influent sewage and activated sludge by high-performance liquid chromatography and photodiode array detection. J Gen Appl Microbiol 42, 457-469.

Im, W.-T., Liu, Q.-M., Yang, J.-E., Kim, M.-S., Kim, S.-Y., Lee, S.-T. \& Yi, T.-H. (2010). Panacagrimonas perspica gen. nov., sp. nov., a novel member of Gammaproteobacteria isolated from soil of a ginseng field. J Microbiol 48, 262-266.

Kim, M.-K., Lee, J.-W., Lee, K.-Y. \& Yang, D.-C. (2005). Microbial conversion of major ginsenoside $\left.\mathrm{rb}_{1}\right)$ to pharmaceutically active minor ginsenoside rd. J Microbiol 43, 456-462.

Kim, J. H., Kim, K. Y. \& Cha, C. J. (2009). Flavobacterium chungangense sp. nov., isolated from a freshwater lake. Int J Syst Evol Microbiol 59, 1754-1758.

Kimura, M. (1983). The Neutral Theory of Molecular Evolution. Cambridge: Cambridge University Press.

Kumar, S., Nei, M., Dudley, J. \& Tamura, K. (2008). MEGA: a biologistcentric software for evolutionary analysis of DNA and protein sequences. Brief Bioinform 9, 299-306.

Liu, Q.-M., Im, W.-T., Lee, M., Yang, D.-C. \& Lee, S.-T. (2006). Dyadobacter ginsengisoli sp. nov., isolated from soil of a ginseng field. Int J Evol Syst Microbiol 56, 1939-1944. 
Liu, Y., Jin, J. H., Zhou, Y. G., Liu, H. C. \& Liu, Z. P. (2010) Flavobacterium caeni sp. nov., isolated from a sequencing batch reactor for the treatment of malachite green effluents. Int J Syst Evol Microbiol 60, 417-421.

Mesbah, M., Premachandran, U. \& Whitman, W. B. (1989). Precise measurement of the $\mathrm{G}+\mathrm{C}$ content of deoxyribonucleic acid by highperformance liquid chromatography. Int J Syst Bacteriol 39, 159-167. Moore, D. D. \& Dowhan, D. (1995). Preparation and analysis of DNA. In Current Protocols in Molecular Biology, pp. 2-11. Edited by F. W. Ausubel, R. Brent, R. E. Kingston, D. D. Moore, J. G. Seidman, J. A. Smith \& K. Struhl. New York: Wiley.

Qu, J. H., Li, H. F., Yang, J. S. \& Yuan, H. L. (2008). Flavobacterium cheniae sp. nov., isolated from sediment of a eutrophic reservoir. Int J Syst Evol Microbiol 58, 2186-2190.

Saitou, N. \& Nei, M. (1987). The neighbor-joining method: a new method for reconstructing phylogenetic trees. Mol Biol Evol 4, 406-425.
Sasser, M. (1990). Identification of bacteria by gas chromatography of cellular fatty acids, MIDI Technical Note 101. Newark, DE: MIDI Inc.

Stackebrandt, E. \& Goebel, B. M. (1994). Taxonomic note: a place for DNA-DNA reassociation and 16S rRNA sequence analysis in the present species definition in bacteriology. Int J Syst Bacteriol 44, 846849.

Thompson, J. D., Gibson, T. J., Plewniak, F., Jeanmougin, F. \& Higgins, D. G. (1997). The CLUSTAL_X windows interface: flexible strategies for multiple sequence alignment aided by quality analysis tools. Nucleic Acids Res 25, 4876-4882.

Wayne, L. G., Brenner, D. J., Colwell, R. R., Grimont, P. A. D., Kandler, O., Krichevsky, M. I., Moore, L. H., Moore, W. E. C., Murray, R. G. E. \& other authors (1987). International Committee on Systematic Bacteriology. Report of the ad hoc committee on reconciliation of approaches to bacterial systematics. Int J Syst Bacteriol 37, 463-464. 